\title{
Implementasi Teknologi Informasi di Bidang Kesehatan
}

\section{Dewi Ratna Sari}

${ }^{1}$ Faculty Of Computer Universitas Mitra Indonesia

Dewiratnasari.student@umitra.ac.id

\section{PENDAHULUAN}

Pendekatan Keilmuan Computer Science menjadi rujukan dalam implementasi Produk Teknologi. Penerapan Sistem Informasi menjadi hal yang sangat fundamental (Febriani \& Putra, 2013) . Penggunaan penerapan teknologi dimasa sekarang dan masa mendatang menjadi hal yang sangat penting dalam perkembangan intelegensia Technology (Putra \& Febriani, 2017). Produksi aplikasi berbasis Humanity membuat aplikasi berkembang dengan sangat cepat, sisi efektifitas dan sisi efisiensi menjadi hal yang sangat berperan dalam perkembangan teknologi tersebut (Putra et al., 2018). Sehingga factor dalam pencarian keterbaruan ataupun novelty menjadi hal yang harus dikembangkan diberbagai lini (Putra et al., n.d.).

\section{PERTANYAAN-001}

Berisi deskripsi tentang pertanyaan yang dilontarkan oleh Bpk. Dr. ( c ) Arie Setya Putra, CA, S.Kom, M.T.I ; Menurut anda apakah Infrastruktur Teknologi Informasi menjadi kebutuhan Penting dalam Perusahaan Khususnya Bidang Kesehatan, Berikan Contoh Detailnya? 


\section{HASIL JAWABAN}

Jabarkan Jawaban Anda :

Infrastruktur Teknologi informasi pada rumah sakit sangat lah penting

Contoh detail nya

1. Memudahkan Pasien dalam mencari informasi

2. Mempersingkat waktu tunggu pasien

3. Mempermudah Dokter dan Tenaga medis dalam menolong pasien

4. Meningkatkan derajat kesehatan masyarakat

5. Penyimpanan dan perawatan data menjadi lebih mudah

6. Membuat alur kerja menjadi Lebih sederhana

7. Sebagai alat pemasaran

8. Monitoring secara online

9. Menjangkau pasien menjadi lebih luas

10. Mencegah penularan penyakit

\section{DAFTAR REFERENSI}

Febriani, O., \& Putra, A. (2013). Sistem Informasi Monitoring Inventori Barang Pada Balai Riset Standardisasi Industri Bandar Lampung. Jurnal Informatika Darmajaya, 13(1), 90-98.

Putra, A. S., \& Febriani, O. M. (2017). Knowledge Management Online Application in PDAM Lampung Province. International Conference on Information Technology and Business (ICITB), 1, 181-187.

Putra, A. S., Febriani, O. M., \& Bachry, B. (2018). Implementasi Genetic Fuzzy System Untuk Mengidentifikasi Hasil Curian Kendaraan Bermotor Di Polda Lampung. SIMADA (Jurnal Sistem Informasi Dan Manajemen Basis Data), 1(1), 21-30.

Putra, A. S., Sukri, H., \& Zuhri, K. (n.d.). Sistem Monitoring Realtime Jaringan Irigasi Desa (JIDES) Dengan Konsep Jaringan Sensor Nirkabel. IJEIS (Indonesian Journal of Electronics and Instrumentation Systems), 8(2), 221-232. 